\title{
Prawo dziecka do edukacji w pracy opiekuńczo-wychowawczej instytucji pieczy zastępczej
}

\begin{abstract}
ABSTRAKT
Artykuł podejmuje problem prawa do edukacji dzieci umieszczonych $w$ instytucjach pieczy zastępczej. Aby określić, jak prawo dziecka do nauki jest realizowane w praktyce pedagogicznej, przeprowadzono badania $w$ jednej $z$ placówek opiekuńczo-wychowawczych typu socjalizacyinego $w$ województwie lubelskim. Celem tych badań było ustalenie stopnia realizacji tego prawa $w$ instytucjonalnej formie opieki, jak również zakresu indywidualnej pomocy wspierającej przebieg edukacji dziecka. W toku badań poszukiwano odpowiedzi na następujqqce problemy badawcze: Jakie formy oddziaływań edukacyjnych wobec wychowanków podejmowane były w instytucji pieczy zastępczej? Jakie formy kształcenia zawodowego podejmowali wychowankowie? Jakie formy pomocy wychowankom w wyborze kierunku kształcenia zapewniała placówka? W jaki sposób kadra pedagogiczna pomagała wychowankom w osiqgnięciu przez nich powodzenia szkolnego? Jakie działania na rzecz stymulowania rozwoju intelektualnego wychowanków były podejmowane w placówce? $\mathrm{Z}$ jakich form terapii korzystali w badanym okresie wychowankowie?
\end{abstract}

SLOWA KLUCZOWE dziecko, dzieciństwo, dziecko osierocone, prawa dziecka, edukacja, rozwój

\section{KEYWORDS}

child, childhood, orphaned child, children's rights, education, development

SPI Vol. 22, 2019/3

ISSN 2450-5358

e-ISSN 2450-5366

DOI: 10.12775/SPI.2019.3.008

Nadestano: 24.04.2019 Zaakceptowano: 30.10.2019

Miscellanea 
W badaniach wykorzystano metodę sondażu diagnostycznego oraz techniki badania dokumentów i ankiety. $Z$ badań wynika, że młodzież $w$ wieku ponadgimnazjalnym wybierała najczęściej szkoły zawodowe, licea i technika, a tylko mała grupa wychowanków kontynuowała naukę w szkołach policealnych $(3,22 \%)$ i na studiach wyższych $(3,22 \%)$. Nauka dzieci była wspierana przez specjalistyczne zajęcia poświęcone wyrównywaniu braków dydaktycznych i niwelowaniu deficytów rozwojowych. Z przeprowadzonych badań wynika potrzeba dalszej profesjonalizacji oddziaływań opiekuńczo-wychowawczych i terapeutycznych wobec dzieci osieroconych umieszczanych w instytucjach pieczy zastępczej.

\section{ABSTRACT}

The article addresses the problem of the right to education of children placed in foster care homes. In order to examine how the child's right to education is implemented in pedagogical practice, research was carried out in one of the educational care center in the Lublin province. The purpose of this research was to determine the degree of implementation of this right in foster care institutions, as well as the scope of individual assistance supporting the child's education. The research was aimed at searching the answers to the following research problems: What forms of educational influence on juveniles were undertaken in foster care home? What forms of vocational training were usually chosen by the pupils? What forms of support did the institution of foster care provide to the pupils in order to help them to choose their future education? How did the teaching staff support the pupils in achieving their school success? What actions stimulating the intellectual development of the pupils were undertaken in the above institution? What forms of therapy were available to the pupils in the examined period?

The research was carried out with the use of the diagnostic survey method as well as the techniques of documents examination and questionnaire. Research shows that young people in upper secondary school most often chose vocational schools, high schools and technical schools, and only a small group of juveniles continued their education in post-secondary schools (3.22\%) and universities (3.22\%). Education was supported by specialized classes dedicated to flattening didactic deficiencies and eliminating developmental deficits. The research shows the need for further professionalization of care, upbringing and therapeutic interactions with orphaned children placed in foster care institutions. 


\section{Dzieciństwo z perspekływy nauk humanistycznych}

W XXI wieku zauważa się wzrost zainteresowania nauk humanistycznych „badaniami nad dzieciństwem”. Jest to spowodowane między innymi potrzebą interdyscyplinarnego podejścia do samej istoty dzieciństwa oraz dziecka, jak i jego szeroko pojętego dobra. Naukowej ocenie, a często też krytyce, poddawane są środowiska wychowawcze, systemy opieki i edukacji dzieci. Analizom naukowym w obszarze badań nad dzieciństwem podlegają także prawa dziecka i ich realizacja zarówno w rodzinie, jak i w instytucjach sprawujących opiekę w jej zastępstwie.

Dziecko i dzieciństwo są bardzo różnie postrzegane i definiowane przez przedstawicieli nauk humanistycznych. W wiekach średnich dziecko postrzegane było jako „miniatura” osoby dorosłej. Wizerunku dzieci nie przedstawiano w sztuce aż do XII wieku, a kiedy postacie dziecięce zaczęły być w niej obecne, wyglądem (proporcjami ciała, kształtem, ubiorem) przypominały pomniejszone postacie osób dorosłych. Richard Farson stwierdził, że dzieci są „wynalazkiem” XVI wieku, gdyż wcześniej w ogóle nie używano słowa „dziecko”. Można więc sądzić, że zarówno dziecko, jak i dzieciństwo nie miały w tamtych czasach szczególnego znaczenia, a potrzeby dzieci oceniano przez analogię do tych, jakie mają ludzie dorośli. W dobie renesansu jezuici z troską określali dzieci jako „delikatne stworzenia Boże, wymagające zarówno opieki i bezpieczeństwa, jak i nawrócenia” (Farson 1992: 42), a dzieciństwo zaczęto rozumieć jako okres przygotowujący do dorosłości. W XVII wieku postrzegano dzieci jako istoty niewinne, chroniąc je przed tematami przeznaczonymi dla dorosłych. Kontynuował tę ideę Jan Jakub Rousseau (1712-1778), który postrzegał dziecko jako ucieleśnienie czystości, niewinności oraz dobroci i uważał, że choćby $\mathrm{z}$ tego powodu powinno być chronione przed negatywnym wpływem świata zewnętrznego. John Locke w swojej filozofii przyjął tezę, że dzieci rodzą się jako tabula rasa, jednak dzięki odpowiedniemu postępowaniu wychowawczemu rodziców i nauczycieli mogą się stać pełnowartościowymi, myślącymi osobami. W takiej koncepcji dziecko jawi się jako „istota podlegająca nieustannemu procesowi stawania się, dochodzenia do dorosłości, posiadająca szczególne potrzeby edukacyjne, które dorośli powinni traktować poważnie" (Kehily 2008: 20), a dorośli są tymi, 
którzy odpowiadają moralnie za zapewnienie dzieciom warunków do edukacji i rozwoju. Historyczne podejście do dzieciństwa reprezentowane przez Henry'ego Mayhewa - brytyjskiego badacza losów dziewiętnastowiecznych rodzin robotniczych - przedstawia je ,jako okres życia, w którym należy oddawać się zabawie i beztroskim przyjemnościom, kiedy dziecko chronione jest przed wpływem realiów świata pracy dorosłych, otoczone troską, trzymane w cieple i dobrze odżywiane" (Kehily 2008: 17). Thomas John Barnardo po zetknięciu się w latach 90 . XX wieku z dziećmi ulicy, które trafiały do sierocińca, uznał, że dzieci osierocone „mają tylko jedną szansę na dzieciństwo. Zasługują na to, aby chronić je przed skrzywdzeniem, by mogły cieszyć się dobrym stanem zdrowia fizycznego i psychicznego oraz równowagą emocjonalną i mieć poczucie przynależności do swojego domu, szkoły i lokalnej społeczności” (Kehily 2008: 18). Podkreślał także swoją wiarę w to, „że nigdy nie jest za wcześnie lub za późno na podanie pomocnej dłoni - i ofiarowanie najbardziej skrzywdzonym przez los młodym ludziom szansy na lepsze dzieciństwo i jaśniejszą przyszłość” (Kehily 2008: 18). Z perspektywy socjologicznej według Allison James i Alana Prouta - „dzieci są i powinny być widziane jako podmioty aktywnie konstruujące i określające swoje życie społeczne, życie otaczających je ludzi i społeczności, w których żyją. Dzieci nie są bowiem jedynie elementami struktur i procesów społecznych" (James, Prout 1990: 9).

Problematyce dziecka i dzieciństwa poświęcił swoją pracę i życie Janusz Korczak, który starał się zrozumieć i określić istotę dziecka jako osoby i dzieciństwa - okresu prowadzącego dziecko ku dorosłości. Próbując określić kim są dzieci, twierdził, że „nie ma dzieci - są ludzie, ale o innej skali pojęć, innym zasobie doświadczenia, innych poglądach, innej grze uczuć" (Korczak 1987: 11). Chcąc wykazać różnice pomiędzy dziećmi a dorosłymi, podkreślał, że „Dzieci różnią się od dorosłych, w ich życiu czegoś brak, a czegoś jest więcej niż w naszym, ale to odmienne od naszego życie jest rzeczywistością, nie przywidzeniem" (Korczak 1992: 40). Na podstawie swoich obserwacji stwierdził, że dziecko „w dziedzinie uczuć przewyższa nas siłą przez nieurobienie hamulców. W dziedzinie intelektu co najmniej nam dorównywa, tylko mu brak doświadczenia. Dlatego tak często dojrzały bywa dzieckiem, a ono dojrzałym człowiekiem, a swoją wrażliwością dziecko często przewyższa dorosłe osoby" 
(Korczak 1992: 62). W dziecku - w tym także dziecku osieroconym - Korczak dostrzegał i doceniał naturalną chęć poznawania świata, eksperymentowania i zdobywania wiedzy. Dziecko „nie mogąc żyć bezczynnie, wejdzie w każdy kąt, zajrzy do każdej szparki (...); ciekawy dla niego ruchomy punkcik mrówki, błyszczący paciorek, zasłyszany wyraz czy zdanie (...)” (Korczak 1992: 68). Dorośli często deprecjonują możliwości intelektualne dziecka przyjmując jak pisał Korczak - że „nie czytało”, „nie umie”, „nie ma nic do powiedzenia” (Wołoszyn 1982: 59), jednak „dziecko chce, by je traktowano poważnie, żąda zaufania, wskazówki, rady" (Korczak 1992: 100). Korczakowi niestety nie do końca się udało znaleźć odpowiedź na pytanie o istotę dzieciństwa. Dla niego głównym dylematem był problem natury dziecka, jego potencjału i wpływu wychowania na kształtowanie osobowości dziecka. Swoje wątpliwości w tej kwestii wyraził w książce Jak kochać dziecko, w której między innymi próbował odpowiedzieć na pytanie: Czy dziecko rodzi się jako tabula rasa? Twierdził - zajmując stanowisko pośrednie - że „dziecko jest pergaminem szczelnie zapisanym drobnymi hieroglifami. Których część tylko zdołamy odczytać, a niektóre potrafimy wytrzeć lub tylko zakreślić i własną zapełnić treścią" (Korczak 1992: 10). Odwołując się do naturalistycznej koncepcji Rousseau, był za tym, aby dorośli czuli się odpowiedzialni za tworzenie warunków sprzyjających swobodnemu rozwojowi dziecka, ale w taki sposób, aby zdobywane przez nie doświadczenia były zgodne $z$ normami życia społecznego i przyczyniały się do prawidłowego kształtowania jego osobowości.

$\mathrm{W}$ indywidualnym procesie wychowania dziecko największą satysfakcję przeżywa wówczas, gdy może się wykazać samodzielnością w praktycznym działaniu i poznawaniu otaczającego je świata. W tym przedmiocie Korczak radził: „Jeśli umiecie diagnozować radość dziecka i jej natężenie, musicie dostrzec, że najwyższą jest radość pokonanej trudności, osiągniętego celu, odkrytej tajemnicy. Radość triumfu i szczęście samodzielności, opanowania, władania” (Korczak 1992: 44).

Korczakowska myśl pedagogiczna wyraźnie nasycona jest autentyczną troską o dziecko i takie pokierowanie jego rozwojem, aby dzieciństwo było szczęśliwym okresem w jego życiu i by dziecko zostało odpowiednio przygotowane do udziału w życiu dorosłych. $Z$ całą pewnością prekursorem tak pojmowanej opieki nad dzieckiem 
był Korczak - lekarz i pedagog, który łączył fachową opiekę z odpowiedzialnością za losy dzieci osieroconych.

\section{„Zagrożone dzieciństwo" wychowanków powierzonych pieczy zastępczej}

Do instytucji pieczy zastępczej trafiają zarówno sieroty naturalne, w tym także półsieroty, jak i sieroty społeczne (stanowiące ok. 95\% wychowanków tych placówek), których rodzice, pomimo tego, że żyją, nie chcą, nie potrafią lub nie mogą sprawować nad nimi opieki. W rodzinach sierot społecznych występują problemy, które dotyczą zarówno relacji pomiędzy rodzicami czy rodzicami a dziećmi, zaburzeń w obrębie struktury takich rodzin. Do tego nierzadko dochodzą choroby, a także przejawy patologii, które osłabiają funkcjonowanie rodziny i zaburzają w istotny sposób warunki rozwoju dziecka. Wśród przyczyn zaburzających funkcjonowanie rodziny i leżących $\mathrm{u}$ podstaw sieroctwa społecznego dzieci $\mathrm{w}$ literaturze przedmiotu wymienia się:

- alkoholizm i inne uzależnienia,

- choroby psychiczne,

- przemoc fizyczną lub psychiczną, maltretowanie i wykorzystywanie seksualne,

- psychiczne opuszczenie dzieci (nieobecność emocjonalna rodziców, chłód emocjonalny),

- czynne odrzucanie i dewaluowanie dziecka,

- nadużycia emocjonalne, czyli używanie dziecka przez dorosłego do zaspokajania swoich potrzeb emocjonalnych (np. czynienie $\mathrm{z}$ niego powiernika spraw dorosłych, tworzenie koalicji $\mathrm{z}$ dzieckiem przeciw drugiemu rodzicowi),

- stawianie nieadekwatnych do poziomu rozwoju i możliwości dziecka wymagań,

- infantylizowanie dziecka lub żądanie spełniania przez nie własnych oczekiwań,

- przerost sztywnych wymagań nad okazywaniem miłości i czułości,

- nadopiekuńczość i nadmierną kontrolę (Bejger 2016: 260). 
Instytucja pieczy zastępczej, jaką jest placówka opiekuńczo-wychowawcza typu socjalizacyjnego, ma do zrealizowania szereg zadań, w tym przede wszystkim: dbanie o rozwój wychowanków, odbudowanie ich relacji z rodzicami i ewentualny powrót do rodziny naturalnej. Dlatego zaraz po przyjęciu do placówki sporządza się diagnozę psychofizyczną dziecka, ustala się jego mocne i słabe strony $\mathrm{w}$ funkcjonowaniu oraz przy współpracy $\mathrm{z}$ asystentem rodziny opracowuje się indywidualny plan pomocy dziecku. Placówka zapewnia każdemu wychowankowi dobre warunki bytowe, opiekę zdrowotną oraz podejmuje różnorodne działania: socjalizacyjne, edukacyjne, opiekuńcze i terapeutyczne, zapewniające dziecku warunki dalszego prawidłowego rozwoju psychofizycznego, wykorzystania swoich potencjałów, osiągania sukcesu szkolnego, tworzenia atmosfery życzliwości i zaufania w grupie oraz oddziaływania specjalistyczne pomagające w niwelowaniu deficytów rozwojowych i przygotowaniu do samodzielnego życia w przyszłości.

\section{Prawo dziecka do edukacji w świetle Konwencji o Prawach Dziecka i ustawodawstwa polskiego}

Konwencja o Prawach Dziecka, uchwalona przez Zgromadzenie Ogólne Narodów Zjednoczonych 20 listopada 1989 roku, ustaliła status dziecka oparty na następujących założeniach:

- dziecko jest samodzielnym podmiotem. Ze względu na swoją niedojrzałość psychiczną i fizyczną wymaga szczególnej opieki i ochrony prawnej;

- dziecko jako istota ludzka wymaga poszanowania jego tożsamości, godności, prywatności;

- rodzina jest najlepszym środowiskiem wychowania dziecka;

- państwo ma wspierać rodzinę, a nie wyręczać ją w jej funkcjach (Czyż 1992: 14).

Jak twierdzi Justyna Stadniczeńko, Konwencja o Prawach Dziecka jest najważniejszym aktem prawa międzynarodowego poświęconym w całości dzieciom (Stadniczeńko 2015: 160). Prawo do nauki stanowi jedno z praw zaliczanych do kategorii praw kulturalnych i w Konwencji zostało ujęte w dwóch artykułach: art. 28 i 29. Treść art. 28 Konwencji zobowiązuje państwa-strony do podejmowania 
działań legislacyjnych i organizacyjnych sprzyjających powszechnej dostępności nauki dla wszystkich dzieci. Nauczanie podstawowe jest dla nich obowiązkowe i bezpłatne, a szkolnictwo średnie i zawodowe jest w wielu krajach dostępne dla wszystkich chętnych. Młodzież uzdolniona w Polsce ma szansę kontynuowania nauki na wyższych uczelniach, które w systemie studiów stacjonarnych są dostępne i bezpłatne. Dzieci w szkołach powinny się spotykać z życzliwością i wychowywać w atmosferze akceptacji oraz gotowości do pomocy, co ma umożliwić wszystkim ukończenie rozpoczętej nauki i ograniczać zjawisko jej porzucania.

Prawo dziecka do nauki ściśle wiąże się z realizacją obowiązku szkolnego, który polega na wymogu ukończenia szkoły podstawowej do czasu uzyskania przez ucznia pełnoletności, tj. ukończenia 18 roku życia (Konstytucja... art. 70, pkt 1). W uzasadnionych sytuacjach rozpoczęcie nauki w szkole podstawowej może być odroczone o jeden rok, a w przypadku dzieci uczących się w szkołach specjalnych do końca roku szkolnego, w którym uczeń kończy 10 lat. Dzieci z niepełnosprawnością, niedostosowane społecznie i zagrożone niedostosowaniem społecznym mają takie samo prawo do nauki (a także wychowania i opieki) jak dzieci zdrowe i funkcjonujące prawidłowo.

Artykuł 29 Konwencji koncentruje się nie tyle na dostępie dzieci do edukacji, co na jej treści. W procesie edukacji dziecka wszystkie oddziaływania szkoły czy placówki powinny się skupiać na „maksymalnym rozwijaniu osobowości, talentów oraz zdolności fizycznych i umysłowych dziecka" (Jaros, Michalak 2015: 383), eksponując tym samym wrodzoną godność dziecka i jego potencjał, który w procesie edukacji powinien być rozwijany. Szczególnie ważna, ze względu na dzieci osierocone wychowujące się w systemie pieczy zastępczej, jest art. 29, pkt d, który za jeden $z$ istotnych celów edukacji uznaje przygotowanie dziecka do życia w społeczeństwie „w duchu zrozumienia, pokoju, tolerancji, równości płci oraz przyjaźni pomiędzy wszystkimi ludźmi, grupami etnicznymi, narodowymi i religijnymi, a także osobami rdzennego pochodzenia" (Jaros, Michalak 2015: 383). Chroniąc podmiotowość i godność każdego dziecka, zapis tego artykułu broni je przed dyskryminacją, ksenofobią i stygmatyzacją ze względu na niepełnosprawność, chorobę, deficyty rozwojowe, rasę, płeć czy pochodzenie. 
Zaniedbywanie realizacji obowiązku szkolnego, co często ma miejsce w rodzinach dysfunkcyjnych, stanowi realne zagrożenie dobra dziecka i nierzadko zaburza jego prawidłowy rozwój. Obowiązki państwa wobec dzieci osieroconych reguluje Konstytucja Rzeczypospolitej Polskiej oraz Kodeks rodzinny i opiekuńczy. Art. 72, ust. 2 Konstytucji RP stanowi, że „Dziecko pozbawione opieki rodzicielskiej ma prawo do opieki i pomocy władz publicznych", natomiast ust. 3 podkreśla, że „W toku ustalania praw dziecka organy władzy publicznej oraz osoby odpowiedzialne za dziecko są obowiązane do wysłuchania i w miarę możliwości uwzględnienia zdania dziecka" (Konstytucja... art. 72, pkt 3; Kodeks rodzinny 2012).

Podstawowym aktem prawnym w Polsce regulującym naukę dzieci w szkołach podstawowych, gimnazjach, szkołach zawodowych i średnich jest ustawa o systemie oświaty (Ustawa o systemie oświaty 2018). Preambuła ustawy podkreśla: „Szkoła winna zapewnić każdemu uczniowi warunki niezbędne do jego rozwoju, przygotować go do wypełniania obowiązków rodzinnych i obywatelskich w oparciu o zasady solidarności, demokracji, tolerancji, sprawiedliwości i wolności" (Ustawa o systemie oświaty 2018). W tym zakresie dziecko osierocone, będące wychowankiem instytucji pieczy zastępczej, powinno być traktowane podobnie jak jego rówieśnicy z prawidłowo funkcjonujących rodzin, jednak ze zwróceniem szczególnej uwagi na jego potrzeby edukacyjne wynikające $z$ kryzysu, jaki panuje w rodzinie dziecka. Szkoła i placówka opiekuńczo-wychowawcza pracują na rzecz dobra dziecka i dlatego pracownicy pedagogiczni tych placówek powinni aktywnie współpracować ze szkołami, do których uczęszczają ich wychowankowie. Obowiązki instytucji pieczy zastępczej w zakresie oddziaływań edukacyjnych wobec dzieci reguluje ustawa z dnia 9 czerwca 2011 r. o wspieraniu rodziny i systemie pieczy zastępczej (Ustawa o wspieraniu rodziny 2011). Placówka zgodnie z ustawą przygotowuje swoich wychowanków do: „a) godnego, samodzielnego i odpowiedzialnego życia; b) pokonywania trudności życiowych zgodnie z zasadami etyki; c) (...) zdobywania umiejętności społecznych" (Ustawa o wspieraniu rodziny 2011: art. 33, pkt 2a) oraz zapewnia zaspokojenie potrzeb: emocjonalnych, bytowych, zdrowotnych edukacyjnych i kulturalno-rekreacyjnych (Ustawa o wspieraniu rodziny 2011: art. 33, pkt 3). Wychowankom pełnoletnim, którzy nadal się uczą „w szkole, zakładzie kształcenia nauczycieli, w uczelni, 
u pracodawcy w celu przygotowania zawodowego" (Ustawa o wspieraniu rodziny 2011: art. 37, pkt 2) umożliwia się, za zgodą dyrektora placówki, przedłużenie pobytu w placówce do 25 roku życia.

Oddziaływania edukacyjne wobec dziecka w instytucji pieczy zastępczej realizowane są w ramach planu pomocy dziecku po wcześniejszej analizie procesu rozwoju psychicznego i fizycznego dziecka, środowiska, z którego ono pochodzi, a także po ustaleniu potrzeb dziecka w sferze opiekuńczej, rozwojowej, emocjonalnej, więzi z rodziną, relacji społecznych i funkcjonowania w grupie i środowisku rówieśniczym i szkolnym" (Rozporzqdzenie Ministra Pracy i Polityki Spotecznej 2011: 15), ustaleniu wpływu sytuacji rodzinnej na rozwój i funkcjonowanie dziecka i dokonaniu analizy jego rozwoju edukacyjnego. W celu zapewnienia powodzenia szkolnego instytucja pieczy zastępczej zobowiązana jest zapewnić każdemu dziecku w wieku szkolnym:

- dostęp do kształcenia dostosowanego do wieku dziecka i jego możliwości rozwojowych (por. Ustawa o wspieraniu rodziny 2011: art. 33);

- podręczniki, pomoce i przybory szkolne;

- pomoc w nauce, w szczególności przy odrabianiu zadań domowych oraz $\mathrm{w}$ miarę potrzeby przez udział $\mathrm{w}$ zajęciach wyrównawczych;

- uczestnictwo w zajęciach wychowawczych, kompensacyjnych, terapeutycznych i rewalidacyjnych adekwatnych do potrzeb dziecka;

- pobyt w internacie lub bursie, gdy dziecko uczy się poza miejscowością, w której znajduje się placówka;

- pokrywanie kosztów przejazdu z placówki do miejscowości, w której znajduje się szkoła (Rozporzadzenie Ministra Pracy i Polityki Spotecznej 2011: 18).

\section{Założenia mełodologiczne badań}

Przedmiot badań stanowiły działania placówki opiekuńczo-wychowawczej na rzecz realizacji prawa wychowanków do edukacji. Celem tych badań było ustalenie, jakie oddziaływania edukacyjne są podejmowane $\mathrm{w}$ instytucji pieczy zastępczej i w jakich formach instytucja wspiera samodzielne działania dziecka w tym zakresie. 
W toku badań próbowano znaleźć odpowiedź na główny problem badawczy: Jakie formy oddziaływań edukacyjnych wobec wychowanków podejmowane są w instytucji pieczy zastępczej? W związku z tym wydzielono kilka problemów szczegółowych: Jakie formy kształcenia zawodowego podejmowali wychowankowie? Jakie formy pomocy wychowankom w wyborze kierunku kształcenia zapewniała placówka? W jaki sposób kadra pedagogiczna pomagała wychowankom w osiągnięciu przez nich powodzenia szkolnego? Jakie działania na rzecz stymulowania rozwoju intelektualnego wychowanków podejmowane były w placówce? $\mathrm{Z}$ jakich form terapii korzystali w badanym okresie wychowankowie?

W badaniach wykorzystano metodę sondażu diagnostycznego, technikę ankiety, którą przeprowadzono wśród wychowanków i wychowawców, a także technikę badania dokumentów (Pilch 1995: 86-88). W badanym okresie w placówce przebywało 62 wychowanków, których dokumenty (teczki akt osobowych i indywidualne plany pomocy) poddano analizie. $\mathrm{Na}$ ankiety odpowiedziało 12 wychowanków w wieku od 15 lat wzwyż aktualnie przebywających w placówce oraz 10 wychowawców. Badania przeprowadzono w Centrum Administracyjnym Domu Dziecka w Przybysławicach, w Domu Dziecka „Dworek” w Przybysławicach oraz w Domu Dziecka „Nowy Dom” w Przybysławicach, w województwie lubelskim, które funkcjonują na zasadach 14-osobowych grup autonomicznie funkcjonujących. Okres badań obejmował lata 2013-2017. Badania zostały przeprowadzone w 2018 roku.

\section{Realizacja prawa dziecka do edukacji w instytucji pieczy zastępczej w świetle badań}

Zgodnie z Konwencją o Prawach Dziecka (art. 28), Konstytucją Rzeczpospolitej Polskiej i ustawą o systemie oświaty wychowankowie badanej placówki - podobnie jak innych placówek w Polsce - realizują obowiązek szkolny, a także w zależności od swoich uzdolnień kontynuują naukę w szkołach zawodowych i średnich. Szczególnie uzdolniona młodzież studiuje na wyższych uczelniach. Ze względu na trudną sytuację rodzinną wychowanków edukacja stanowi formę „przygotowania (...) do odpowiedzialnego życia w wolnym społeczeństwie" (Konwencja o Prawach Dziecka 2015: 57) i samodzielności 
po opuszczeniu placówki. W badanym okresie w placówce przebywało 62 wychowanków. Wykaz instytucji, w których wychowankowie uczyli się w badanym okresie, przedstawia tabela 1 .

Tabela 1. Instytucje edukacyjne, w których uczyli się wychowankowie w latach 2013-2017

\begin{tabular}{|c|c|c|c|c|c|}
\hline \multirow{3}{*}{ Lp. } & \multirow{3}{*}{ Nazwa instytucji } & \multicolumn{4}{|c|}{$\mathbf{N}=\mathbf{6 2}$} \\
\hline & & \multicolumn{2}{|c|}{ ogólnodostępne } & \multicolumn{2}{|c|}{ specjalne } \\
\hline & & $\mathbf{n}$ & $\%$ & $\mathbf{n}$ & $\%$ \\
\hline 1. & przedszkole & 3 & 4,83 & - & - \\
\hline 2. & szkoła podstawowa (klasy I-VI) & 10 & 16,13 & 2 & 3,22 \\
\hline 3. & gimnazjum & 13 & 20,96 & 1 & 1,61 \\
\hline 4. & zasadnicza szkoła zawodowa & 9 & 14,51 & 8 & 12,90 \\
\hline 5. & szkoła przysposobienia do pracy & - & - & 2 & 3,22 \\
\hline 6. & technikum & 4 & 6,45 & - & - \\
\hline 7. & liceum ogólnokształcq̨ce & 6 & 9,67 & - & - \\
\hline 8. & szkoły policealne & 2 & 3,22 & - & - \\
\hline 9. & wyższe uczelnie & 2 & 3,22 & - & - \\
\hline & Razem & 49 & 79,03 & 13 & 20,96 \\
\hline
\end{tabular}

Źródło: Badania własne.

$Z$ danych ujętych w tabeli 1 wynika, że zgodnie $z$ intencją ustawodawcy, w placówce przebywały przede wszystkim dzieci powyżej dziesiątego roku życia, które uczęszczały do szkoły podstawowej w danej miejscowości (16,13\% ogółu badanych) i do szkół specjalnych $(3,22 \%)$ poza miejscowością ze względu na posiadane orzeczenie o potrzebie kształcenia specjalnego. Dzieci w wieku przedszkolnym $(4,83 \%)$ wraz z pozostałym rodzeństwem zostały objęte edukacją w przedszkolu w Markuszowie. Większość młodzieży w normie intelektualnej $(58,07 \%)$ uczęszczała do gimnazjum (20,96\%), zasadniczych szkół zawodowych (14,51\%), techników (6,45\%), liceów ogólnokształcących (9,67\%), a młodzież o wyższych aspiracjach życiowych i zawodowych do szkół policealnych $(3,22 \%)$ i na wyższe uczelnie $(3,22 \%)$. Studia na wyższych uczelniach podjęło dwoje wychowanków $(3,22 \%)$ na dwóch różnych uczelniach: Politechnice Lubelskiej na kierunku inżynieria środowiska i w Wyższej 
Szkole Społeczno-Przyrodniczej w Lublinie na kierunku wychowanie fizyczne. Oboje (staraniem placówki) otrzymali stypendia od organizacji pozarządowych, ułatwiające zakup książek, materiałów i pokrywające inne koszty związane ze studiowaniem. W związku z kontynuowaniem nauki po uzyskaniu pełnoletności 10 wychowanków (16,13\%) przedłużyło swój pobyt w placówce do czasu ukończenia nauki. Wśród nich znalazło się: 2 uczniów liceum ogólnokształcącego (3,22\%), 4 uczniów technikum (6,45\% ogółu badanych), 2 uczniów szkół policealnych (3,22\%) i 2 studentów wyższych uczelni $(3,22 \%)$. Wszyscy ci wychowankowie byli nadal zobowiązani do przestrzegania regulaminu placówki, ale jednocześnie mieli ogromną pomoc w postaci zapewnienia dobrych warunków bytowych umożliwiających dalszą naukę.

Podejmując naukę w szkołach ponadgimnazjalnych - poza uczniami liceów ogólnokształcących nieprofilowanych - młodzież nastawiona była na uzyskanie konkretnych kwalifikacji zawodowych dających im możliwość podjęcia pracy zarobkowej i zapewniających samodzielne funkcjonowanie w przyszłości.

Tabela 2. Specjalności zawodowe wybierane przez wychowanków w latach 2013-2017

\begin{tabular}{|c|c|c|c|c|}
\hline \multirow{2}{*}{ Lp. } & \multirow{2}{*}{ Poziom edukacji } & \multirow{2}{*}{ specjalność } & \multicolumn{2}{|c|}{$N=62$} \\
\hline & & & $\mathbf{n}$ & $\%$ \\
\hline \multirow{7}{*}{1.} & \multirow{7}{*}{ zasadnicza szkoła zawodowa } & mechanik samochodowy & 1 & 1,61 \\
\hline & & kucharz małej gastronomii & 4 & 6,45 \\
\hline & & kucharz & 4 & 6,45 \\
\hline & & murarz & 1 & 1,61 \\
\hline & & piekarz & 2 & 3,22 \\
\hline & & fryzjer & 2 & 3,22 \\
\hline & & stolarz & 3 & 4,84 \\
\hline 2. & liceum ogólnokształcq̨ce & wojskowa & 1 & 1,61 \\
\hline \multirow{4}{*}{3.} & \multirow{4}{*}{ technikum } & technik hotelarstwa & 1 & 1,61 \\
\hline & & technik budowlany & 1 & 1,61 \\
\hline & & technolog żywienia & 1 & 1,61 \\
\hline & & technik logistyki & 1 & 1,61 \\
\hline
\end{tabular}




\begin{tabular}{|c|c|c|c|c|}
\hline \multirow{2}{*}{ Lp. } & \multirow{2}{*}{ Poziom edukacji } & \multirow{2}{*}{ specjalność } & \multicolumn{2}{|c|}{$\mathbf{N}=62$} \\
\hline & & & $\mathbf{n}$ & $\%$ \\
\hline 4. & szkoły policealne & technik ochrony & 2 & 3,22 \\
\hline \multirow{2}{*}{5.} & \multirow{2}{*}{ wyższe uczelnie } & inżynieria środowiska & 1 & 1,61 \\
\hline & & wychowanie fizyczne & 1 & 1,61 \\
\hline \multicolumn{3}{|c|}{ Razem } & 26 & 41,93 \\
\hline
\end{tabular}

Źródło: Badania własne.

Szerokie spektrum specjalności, jakie wybierali wychowankowie, wskazuje, że nie byli oni typowani do szkół przez kadrę pedagogiczną placówki, ale kierowali się swoimi zainteresowaniami i uzdolnieniami. W szkołach zawodowych wychowankowie wybierali zawody: kucharz małej gastronomii - najczęściej w szkołach specjalnych $(6,45 \%)$, kucharz $(6,45 \%)$, stolarz $(4,84 \%)$, a także piekarz $(3,22 \%)$ i fryzjer $(3,22 \%)$ - w szkołach ogólnodostępnych, zaś pojedyncze osoby wybrały zawód murarza $(1,61 \%)$ i mechanika samochodowego $(1,61 \%)$. W liceach i technikach pojedynczy wychowankowie (po 1,61\%) wybrali specjalności: wojskową, hotelarską, budowlaną, żywieniową i logistyczną. W szkole policealnej wybrali $(3,22 \%)$ zawód technika ochrony. W związku ze zbliżającym się usamodzielnieniem kilku wychowankom (8,06\%) udało się dodatkowo ukończyć kursy stanowiące cenne uzupełnienie edukacji szkolnej: kurs obsługi kas fiskalnych $(4,84 \%)$, kurs prawa jazdy $(1,61 \%)$ i kurs technologa robót wykończeniowych (1,61\%).

Tabela 3. Pomoc w wyborze szkoły ponadgimnazjalnej według opinii wychowanków w wieku powyżej 15 lat

\begin{tabular}{|c|l|c|c|}
\hline \multirow{2}{*}{ Lp. } & \multicolumn{1}{|c|}{ Osoba/instytucja udzielająca pomocy } & \multicolumn{2}{|c|}{$\mathbf{N}=12$} \\
\cline { 3 - 4 } & \multicolumn{1}{|c|}{$\mathbf{n}$} & $\%$ \\
\hline 1. & poradnia psychologiczno-pedagogiczna & 2 & 16,67 \\
\hline 2. & dyrektor placówki & - & - \\
\hline 3. & wychowawca & 9 & 75,00 \\
\hline 4. & psycholog & 2 & 16,67 \\
\hline 5. & pedagog & 1 & 8,33 \\
\hline 6. & nauczyciel ze szkoły podstawowei/gimnazjum & - & - \\
\hline 7. & samodzielna decyzja wychowanka & 1 & 8,33 \\
\hline
\end{tabular}

Źródło: badania własne. 
W podejmowaniu decyzji o wyborze szkoły ponadgimnazjalnejjak wynika z przeprowadzonej ankiety - młodzież korzystała przede wszystkim ze wskazówek wychowawców $(75,00 \%)$, inni z pomocy psychologa w placówce $(16,67 \%)$, pedagoga $(8,33 \%)$ lub poradni psychologiczno-pedagogicznej $(16,67 \%)$, czasem $(8,33 \%)$ była to samodzielna decyzja wychowanka.

Tabela 4. Formy pomocy wychowankom w ukończeniu szkoły według opinii wychowanków w wieku powyżej 15 lat

\begin{tabular}{|c|l|c|c|}
\hline \multirow{2}{*}{ Lp. } & \multicolumn{1}{|c|}{ Formy pomocy } & \multicolumn{2}{c|}{ N=12 } \\
\cline { 3 - 4 } & & $\mathbf{1}$ & $\%$ \\
\hline 1. & sprawdzanie obecności w szkole & 11 & 91,67 \\
\hline 2. & ścisłe przestrzeganie godzin nauki własnej & 8 & 66,67 \\
\hline 3. & sprawdzanie prac domowych & 6 & 50,00 \\
\hline 4. & pomoc w przygotowaniu prac pisemnych & 5 & 41,67 \\
\hline 5. & udostępnianie dodatkowych ksiq̨żek i materiałów & 2 & 16,67 \\
\hline 6. & $\begin{array}{l}\text { rozmowa z pedagogiem i psychologiem w sytuacjach trud- } \\
\text { nych }\end{array}$ & 2 & 16,67 \\
\hline
\end{tabular}

Źródło: Badania własne.

Jak wynika z sondażu przeprowadzonego wśród wychowanków, wychowawcy tworzyli warunki organizacyjne sprzyjające realizacji prawa dzieci do edukacji poprzez: sprawdzanie obecności wychowanków w szkole (91,67\% odpowiedzi), ścisłe przestrzeganie godzin nauki własnej $(66,67 \%)$ oraz sprawdzanie prac domowych $(50,00 \%)$ zapewniających uzyskanie pozytywnych ocen. Ponadto korzystali z pomocy w przygotowaniu prac pisemnych $(41,67 \%)$, a także mieli udostępniane dodatkowe książki i materiały $(16,67 \%)$ poszerzające wiedzę. W sytuacjach trudnych mogli liczyć na pomoc psychologa i pedagoga $(16,67 \%)$. 
Tabela 5. Działania podejmowane w celu zapewnienia sukcesu szkolnego wychowankom według opinii kadry pedagogicznej

\begin{tabular}{|c|c|c|c|}
\hline \multirow{2}{*}{ Lp. } & \multirow{2}{*}{ Formy działań } & \multicolumn{2}{|c|}{$\mathbf{N}=10$} \\
\hline & & $\mathbf{n}$ & $\%$ \\
\hline 1. & wyposażenie w podręczniki i przybory szkolne & 6 & 60,00 \\
\hline 2. & systematyczne przygotowywanie do lekcji & 10 & 100,00 \\
\hline 3. & przestrzeganie dyscypliny w czasie nauki własnej & 7 & 70,00 \\
\hline 4. & indywidualna pomoc w nauce & 10 & 100,00 \\
\hline 5. & badania psychopedagogiczne & 3 & 30,00 \\
\hline 6. & zajęcia korekcyjno-kompensacyjne & 5 & 50,00 \\
\hline 7. & obniżenie progu wymagań & 2 & 20,00 \\
\hline 8. & bieżq̨ca analiza zachowania i postępów w nauce & 5 & 50,00 \\
\hline 9. & nagradzanie za szczególne osiqgnięcia w nauce & 6 & 60,00 \\
\hline 10. & uświadamianie celowości nauki & 5 & 50,00 \\
\hline 11. & stały kontakt z nauczycielami & 7 & 70,00 \\
\hline 12. & $\begin{array}{l}\text { zapewnienie dostępu do ksiq̨żek, encyklopedii, słowników, TV, } \\
\text { radia }\end{array}$ & 7 & 70,00 \\
\hline 13. & pomoc w wyborze szkoły & 5 & 50,00 \\
\hline 14. & organizowanie samopomocy wśród wychowanków & 3 & 30,00 \\
\hline 15. & rozwijanie zainteresowań & 7 & 70,00 \\
\hline
\end{tabular}

Źródło: Badania własne.

Z opinii kadry pedagogicznej, która planuje indywidualne oddziaływania z każdym wychowankiem, wynika, że w badanym okresie wszyscy (100,00\% ankietowanych) systematycznie przygotowywali dzieci do lekcji i zapewniali indywidualną pomoc w nauce; 70,00\% badanych potwierdziło zapewnianie dzieciom dostępu do książek i mediów, rozwijało ich zainteresowania, przestrzegało dyscypliny pracy przy odrabianiu lekcji i umożliwiało stały kontakt z nauczycielami w szkole; $60,00 \%$ kadry wyposażało dzieci w podręczniki i przybory szkolne i starało się nagradzać dzieci za szczególne osiągnięcia w nauce; 50,00\% prowadziło zajęcia korekcyjno-kompensacyjne wyrównujące braki dydaktyczne i niwelujące deficyty rozwojowe, na bieżąco sprawdzało postępy w nauce i zmiany w zachowaniu 
dziecka w szkole, prowadziło rozmowy na temat sensu nauki i pomagało w wyborze dalszego kierunku kształcenia; na poziomie 30,00\% kształtują się wyniki w zakresie dbania o kierowanie dzieci na badania psychopedagogiczne i organizowanie pomocy koleżeńskiej wśród wychowanków, zaś $20,00 \%$ optowało za potrzebą obniżenia, w stosunku do niektórych dzieci, progu wymagań szkolnych ze względu na ograniczone możliwości dziecka poparte opinią psychopedagogiczną.

Tabela 6. Metody stymulowania rozwoju intelektualnego wychowanków według opinii kadry pedagogicznej

\begin{tabular}{|c|c|c|c|}
\hline \multirow{2}{*}{ Lp. } & \multirow{2}{*}{ Stosowane metody stymulacii } & \multicolumn{2}{|c|}{$\mathbf{N}=10$} \\
\hline & & $\mathbf{n}$ & $\%$ \\
\hline 1. & pomoc w nauce & 7 & 70,00 \\
\hline 2. & rozwój zainteresowań & 9 & 90,00 \\
\hline 3. & czytelnictwo ksiqżek i czasopism & 6 & 60,00 \\
\hline 4. & przykład własny & 4 & 40,00 \\
\hline 5. & regularne ocenianie osiq̨gnięć dziecka & 2 & 20,00 \\
\hline 6. & rozwiqzywanie łamigłówek, krzyżówek & 1 & 10,00 \\
\hline 7. & $\begin{array}{l}\text { dostarczanie materiałów będq̨cych źródłem wiedzy (artykuły, } \\
\text { ksiq̨żki, filmy) }\end{array}$ & 2 & 20,00 \\
\hline 8. & motywowanie do pracy nad sobq & 9 & 90,00 \\
\hline 9. & okazywanie radości z sukcesów edukacyjnych dziecka & 7 & 70,00 \\
\hline 10. & gry i programy edukacyine & 6 & 60,00 \\
\hline 11. & zajęcia reedukacyjne & 2 & 20,00 \\
\hline 12. & rozbudzanie ambicji i aspiracji & 6 & 60,00 \\
\hline 13. & konkursy wiedzy & 1 & 10,00 \\
\hline 14. & kontakt z placówkami kultury & 4 & 40,00 \\
\hline
\end{tabular}

Źródło: Badania własne.

Równolegle z dbałością wychowawców o sukces szkolny miał miejsce proces systematycznego stymulowania rozwoju intelektualnego wychowanków, który zwiększał gotowość dzieci do wysiłku umysłowego i tym samym prawdopodobieństwo osiągnięcia powodzenia w edukacji. Dokonywał się on poprzez rozwój zainteresowań i intensywną pracę nad sobą (opinia 90,00\% badanych); 70,00\% 
kadry pomagało w nauce i okazywało radość z sukcesów dziecka, motywując je do dalszej pracy; $60,00 \%$ badanych rozwijało wśród dzieci czytelnictwo prasy i książek, stosowało w pracy gry i programy edukacyjne oraz starało się rozbudzać ambicje i aspiracje edukacyjne dzieci i młodzieży; 40,00\% służyło własnym przykładem i proponowało wyjścia do placówek kultury (kin, teatrów, sal koncertowych, bibliotek, galerii sztuki itp.); 20,00\% kadry starało się regularnie oceniać osiągnięcia edukacyjne wychowanków, dostarczać materiały poszerzające wiedzę dzieci na określone tematy i prowadziło zajęcia edukacyjne; 10,00\% badanych organizowało konkursy wiedzy z różnych dziedzin i proponowało wysiłek umysłowy przy rozwiązywaniu krzyżówek i łamigłówek.

Tabela 7. Formy terapii stosowane w pracy z wychowankami według opinii kadry pedagogicznej

\begin{tabular}{|c|c|c|c|}
\hline \multirow{2}{*}{ Lp. } & \multirow{2}{*}{ Formy terapii } & \multicolumn{2}{|c|}{$\mathbf{N}=10$} \\
\hline & & $\mathbf{n}$ & $\%$ \\
\hline 1. & rozmowa terapeutyczna & 7 & 70,00 \\
\hline 2. & swobodna ekspresja plastyczna, muzyczna, ruchowa & 6 & 60,00 \\
\hline 3. & terapia pedagogiczna & 4 & 40,00 \\
\hline 4. & zajęcia relaksacyjne & 4 & 40,00 \\
\hline 5. & bajkoterapia & 3 & 30,00 \\
\hline 6. & socjoterapia & 2 & 20,00 \\
\hline 7. & trening asertywności & 4 & 40,00 \\
\hline 8. & warsztaty umiejętności interpersonalnych & 2 & 20,00 \\
\hline 9. & pedagogika zabawy & 4 & 40,00 \\
\hline 10. & psychodrama & - & - \\
\hline 11. & psychoterapia & 1 & 10,00 \\
\hline 12. & arteterapia & 2 & 20,00 \\
\hline 13. & terapia przez pracę & 2 & 20,00 \\
\hline
\end{tabular}

Źródło: Badania własne.

Cenne uzupełnienie oddziaływań opiekuńczo-wychowawczych wspierających proces edukacji dzieci stanowiły w badanej placówce 
różne formy terapii poprawiające kondycję psychiczną i intelektualną wychowanków. W opiniach kadry pedagogicznej wśród metod terapii najczęściej stosowanych pojawiała się rozmowa terapeutyczna (70,00\%) oraz swobodna ekspresja plastyczna, muzyczna i ruchowa (60,00\%); 40,00\% respondentów w swojej pracy stosowało: terapię pedagogiczną, zajęcia relaksacyjne, trening asertywności i pedagogikę zabawy; 30,00\% badanych wykorzystywało bajkoterapię; 20,00\% socjoterapię i arteterapię oraz prowadziło warsztaty umiejętności interpersonalnych i ergoterapię; nieliczni (tylko 10,00\%) stosowali psychoterapię.

\section{Wnioski i rekomendacje}

Badana placówka w latach 2013-2017 dbała o realizację nie tylko obowiązku szkolnego, ale także zabiegała o uzyskanie przez wychowanków kwalifikacji zawodowych, które w przyszłości mogą zapewnić im zatrudnienie i godne życie. Typy szkól i profile zawodowe były wybierane zgodnie z potencjalnymi możliwościami intelektualnymi młodzieży, ale też ich zainteresowaniami. Wybierając szkoły, wychowankowie nastawieni byli przede wszystkim na uzyskanie uprawnień zawodowych zapewniających im w przyszłości pracę. Szanse na zdobycie zawodu mieli wszyscy wychowankowie - zarówno prawidłowo funkcjonujący, jak i z niepełnosprawnością intelektualną. Największym zaufaniem w kwestii pomocy w wyborze szkoły i kierunku kształcenia cieszyli się wśród wychowanków wychowawcy $(75,00 \%)$, znacznie mniejszym psycholog $(16,67 \%)$ i pedagog $(8,33 \%)$. Wyniki ankiety wskazują, że w przyszłości placówka powinna w większym stopniu wykorzystać profesjonalnych doradców zawodowych do organizacji cyklicznych spotkań, które dodatkowo pomogłyby wychowankom określić ich własne preferencje i właściwie wybrać ścieżkę dalszej edukacji. Kadra pedagogiczna wspierała wychowanków w ukończeniu podjętej nauki przez właściwą organizację pracy, przestrzeganie godzin przeznaczonych na przygotowywanie się do lekcji oraz pomagała w odrabianiu prac domowych i pokonywaniu wszelkich trudności w nauce. Wychowawcy placówki byli żywo zainteresowani dbaniem o pomyślny przebieg nauki wychowanków i podejmowali konkretne działania w zakresie terapii pedagogicznej wyrównującej braki dydaktyczne i niwelującej deficyty rozwojowe 
oraz motywującej do intensywnej pracy nad sobą. Dodatkowo dzięki wprowadzaniu różnych zajęć umysłowych starali się stymulować rozwój sfery intelektualnej dzieci i młodzieży, zwiększając tym samym ich szansę na ukończenie wybranych szkół i lepsze przygotowanie do samodzielnego życia. Terapię w placówce prowadziło 20,00- 40,00\% kadry pedagogicznej, co wynikało $\mathrm{z}$ posiadanych $\mathrm{w}$ tym zakresie kwalifikacji. Ze względu na ogromne zapotrzebowanie na specjalistyczne oddziaływania w tego typu placówkach, pożądane wydaje się dalsze poszerzanie kompetencji kadry, co umożliwiłoby szersze stosowanie różnych form terapii w codziennej pracy z dziećmi i młodzieżą. Zwiększyłoby to skuteczność pracy opiekuńczo-wychowawczej instytucji pieczy zastępczej i lepiej przygotowywałoby dzieci do rozpoczęcia samodzielnego życia. Wyniki przeprowadzonych badań pozwalają stwierdzić, że praca opiekuńczo-wychowawcza instytucji w zakresie realizacji prawa dziecka do nauki przebiegała właściwie, jednak aby placówki socjalizacyjne funkcjonowały jeszcze lepiej, trzeba nadal zmierzać do pełnej profesjonalizacji oddziaływań, które zgodnie $z$ intencją prawodawcy powinny w jak najpełniejszym zakresie rozwijać osobowość dzieci osieroconych, ich talenty oraz zdolności umysłowe i fizyczne (Konwencja o Prawach Dziecka 2015: 157).

\section{Bibliografia}

Bejger H. (2016). Praca z rodzinami wychowanków w praktyce pedagogicznej placówek opiekuńczo-wychowawczych typu socjalizacyjnego, [w:] H. Bejger, O. Lisovets, R. Kartaszyńska, S. Borysiuk (red.), Wspótczesna rodzina jako środowisko opiekuńczo-wychowawucze, Chełm-Niżyn: Państwowa Wyższa Szkoła Zawodowa, Chełmskie Towarzystwo Naukowe, s. 260-284.

Czyż E. (1992). Konwencja o Prawach Dziecka. Wprowadzenie, [w:] E. Czyż (red.), Dziecko i jego prawa, Warszawa: Biblioteka Komitetu Ochrony Praw Dziecka, s. 3-16.

Farson R. (1992). O wynalezieniu dzieci, [w:] K. Busz (red.), Edukacja i wyzwolenie, Kraków: Oficyna Wydawnicza „Impuls”.

James A., Prout A. (red.). (1990). Constructing and Reconstructing Childhood, Basingstoke: Falmer Press.

Jaros P.J., Michalak M. (2015). Prawa dziecka. Dokumenty Organizacji Narodów Zjednoczonych, Warszawa: Biuro Rzecznika Praw Dziecka.

Kehily M.J. (2008). Zrozumieć dziecinstwo: wprowadzenie w kluczorve tematy i zagadnienia, [w:] M.J. Kehily (oprac.), Wprowadzenie do badań nad dzieciństwem, przeł. M. Kościelniak, Kraków: Wydawnictwo WAM. 
Kodeks rodzinny i opiekuńczy z 25 lutego 1964 r. (Dz.U.2012, poz. 788 ze zm). Konstytucja III Rzeczypospolitej Polskiej. (2011). Warszawa: Mada.

Konwencja o Prawach Dziecka. (2015). [w:] P. Jaros, M. Michalak (red.), Prawa dziecka. Dokumenty Organizacji Narodów Zjednoczonych, Warszawa: Biuro Rzecznika Praw Dziecka.

Korczak J. (1987). Myśli, Warszawa: Państwowy Instytut Wydawniczy.

Korczak J. (1992). Jak kochać dziecko, Warszawa: Oficyna Wydawnicza „Latona”.

Pilch T. (1995). Zasady badań pedagogicznych, Warszawa: Wydawnictwo Akademickie „Żak”.

Rozporzadzenie Ministra Pracy i Polityki Spotecznej z dnia 22 grudnia 2011 r. w sprawie instytucjonalnej pieczy zastępczej (Dz.U. 2011, nr 292, poz. 1720).

Stadniczeńko J. (2015). Prawo dziecka do nauki - prawa w oświacie, [w:] S.L. Stadniczeńko (red.), Konwencja o Prawach Dziecka. Wybór zagadnien (artykuty i komentarze), Warszawa: Biuro Rzecznika Praw Dziecka.

Ustawa o wspieraniu rodziny $i$ systemie pieczy zastępczej z dnia 9 czerwca 2011 r. (Dz.U. 2011, nr 149, poz. 887).

Ustawa o systemie oświaty z 14 grudnia 2016 r. ogtoszona dnia 24 maja 2018 r. (Dz.U. 2018, poz. 996, 1000, 1290, 1669, 2245).

Wołoszyn S. (1982). Korczak, Warszawa: Wiedza Powszechna.

\title{
ADRES DO KORESPONDENCJI
}

\author{
Dr Halina Bejger \\ Państwowa Wyższa Szkoła Zawodowa w Chełmie \\ e-mail: hbejger@wp.pl
}

